\title{
Bacterial Communities in Serpa Cheese by Culture Dependent Techniques, 165 rRNA Gene Sequencing and High-throughput Sequencing Analysis
}

\author{
Maria Teresa P. Gonçalves, María José Benito iD, María de Guía Córdoba, Conceição Egas, Almudena V. Merchán iD, \\ Ana I. Galván, and Santiago Ruiz-Moyano
}

\begin{abstract}
Serpa cheese is one of the traditional regional Portuguese cheeses having the Protected Denomination of Origin (PDO) designation. This study investigated the bacterial community in the traditional Portuguese Serpa cheese. The microorganisms identified at the end of ripening (30 days) mainly were lactic acid bacteria (LAB). Lactobacillus paracasei/Lactobacillus case $i$ was the main species in cheese from PDO registered industries, whereas in non-PDO registered industries Lactobacillus brevis was highlighted, among other LAB. Enterobacteriaceae species were detected at $20 \%$ to $40 \%$ of the total isolates. The results obtained by high-throughput sequencing analysis confirmed that LAB was the main microbial group, with Lactococcus genus contributing to approximately $40 \%$ to $60 \%$ of the population, followed by Leuconostoc and Lactobacillus. The Enterobacteriaceae family was also important. The differences between bacterial communities from PDO and non-PDO registered industries suggest that the lack of regulation of the cheese-making practices may influence unfavorably. The new knowledge about bacterial diversity in Serpa cheese could be useful to set up new ripening conditions, which favor the development of desirable microorganisms.
\end{abstract}

Keywords: cheese, microbial population, traditional cheese

Practical Application: The control of the manufacturing process of traditional cheeses can be improved through the knowledge of the bacterial diversity that develops. Thus, the growth of desirable microorganisms can be promoted to homogenize the final product.

\section{Introduction}

Serpa is an artisanal ripened Portuguese cheese granted the Protected Designation of Origin (PDO) label (Council Regulation EEC 2081/92), with six industries making cheese under this designation, although there are also other producers in the area without following the PDO regulation. It is produced within the Alentejo province (south of Portugal) from raw ewes' milk using aqueous infusion of the dried flowers from Cynara cardunculus L. plant as coagulant and without the addition of a starter culture. The absence of thermal process and starter microorganisms means that its quality and characteristics depend mainly on the endogenous microbiota, which arises primarily from the raw milk, vegetable coagulant and the cheese dairy environment (Aquilanti et al., 2011; Bokulich \& Mills, 2013; Ordiales et al., 2013b; Pereira, Graça, Ogando, Gomes, \& Malcata, 2010a).

$\overline{\text { JFDS-2017-2074 Submitted 12/22/2017, Accepted 3/6/2018. Author Gonçalves }}$ is with the Inst. Politécnico de Beja, Escola Superior Agrária, Beja, Portugal. Authors Benito, Córdoba, Merchán, Galván, and Ruiz-Moyano are with the Nutrición y Bromatología, Escuela de Ingenierías Agrarias, Univ. de Extremadura, Avd. Adolfo Suárez s/n, 06007, Badajoz, Spain. Authors Benito, Córdoba, Merchán, Galván, and Ruiz-Moyano are also with the Inst. Univ. de Investigación en Recursos Agrarios (INURA), Avd. De la Investigación s/n, Univ. de Extremadura, 06006, Badajoz, Spain. Author Egas is with the UCBiotech-CNC, BiocantPark, Núcleo 04, Lote 08, 3060-197, Cantanhede, Portugal. Direct inquiries to author Benito (E-mail: mjbenito@unex.es).
Most of the microbial community present in raw milk are lactic acid bacteria (LAB) (Lactococcus spp., Lactobacillus spp., and Enterococcus spp.), but microorganisms, such as Enterobacteriaceae, coliforms, Staphylococcus aureus, Pseudomonas spp., or even Listeria monocytogenes may also be present, and this raises the potential of public health risks (Pereira et al., 2010a). Hence, controlling the microbial communities during cheese production is the main factor to ensure food safety and the sensorial properties of the final product (Coton et al., 2012). During cheese ripening, the microbiota is mainly dominated by various LAB species, and to a lesser extent by cocci Gram-positive catalase-positive, diverse Gramnegative bacteria (Citrobacter spp., Enterobacter spp., Pseudomonas spp., Serratia spp. and Hafnia spp.), yeasts and molds (Abriouel, Martín-Platero, Maqueda, Valdivia, \& Martínez-Bueno, 2008; Ordiales et al., 2013a; Dos Santos, Benito, Córdoba, Alvarenga, \& Ruiz-Moyano, 2017). The contribution of LAB to the cheese final organoleptic characteristics is a consequence of their ability to ferment lactose and their proteolytic activity (Menéndez, Centeno, Godínez,\& Rodríguez-Otero, 2000).

The properties of the resulting cheese can be expected to vary between producers due to small differences in the cheese making technology and slight variations in the chemical and microbial composition of the milk associated with the conditions of milk production, such as hygiene, geographical area, animal breed, season, and the microbial population of the cheese making environment (Alessandria et al., 2016; Bokulich \& Mills, 2013; Guiné, Tenreiro, Correia, Correia, \& Barracosa, 2016; Pereira 
et al., 2010b). A thorough microbial survey of similar cheeses regarding their origin and production technology, as PDO and non-PDO cheeses, could be very important for the dairy industry, as the PDO regulation enables knowledge of the production technology and milk production conditions to guarantee the quality of the product.

Accurate identification of microorganisms requires a culturedependent approach combined with mainly DNA-based molecular techniques (Bokulich \& Mills, 2013; Ordiales et al., 2013a). Sequencing the $16 \mathrm{~S}$ rRNA gene in bacteria is a suitable tool for describing the microbial diversity of food process. Identifying live microorganisms along the cheese making process may contribute to establish strategies to control the microbial population and their influence on the final cheese characteristics (Ordiales et al., 2013b). However, the advent of culture independent technique such as high-throughput sequencing (HTS) technology has revolutionized the study of microbial ecosystems, including food fermentations. High-throughput sequencing enables comprehensive microbial surveys with detection sensitivities and throughputs several orders of magnitude greater than earlier molecular techniques via massive parallel sequencing of short amplicons of universally conserved DNA fragments, typically the 16S rRNA gene in bacteria (Bokulich \& Mills, 2013). Thus, HTS tools have superior sequence coverage (live and death cells during the whole process) and lower sequencing cost, but the shorter fragment length results in lower taxonomic resolution (Bokulich \& Mills, 2012).

Although Serpa cheese is considered one of the most appreciated Portuguese cheeses for its sensorial characteristic, little is known about the microbial diversity of this traditional cheese. Therefore, the aim of the present work was to study the bacterial community and foodborne pathogens presence in Serpa cheese with PDO label in comparison with similar non-PDO registered cheeses of the area by culture dependent and independent methods.

\section{Materials and Methods}

\section{Serpa cheese samples}

Samples were taken at the end of the ripening process (30 days) from 5 different dairy industries located in the geographical area of production. Three industries, identified as A, C, and G belonged to PDO "Serpa cheese," while the non-PDO registered industries were designated as $\mathrm{V}$ and $\mathrm{B}$. Serpa cheeses were manufactured after raw ewes' milk coagulation with a Cynara cardunculus L. flowers infusion as described Alvarenga, Canada, and Sousa (2011). Ripened cheeses have a cylindrical shape with around $800 \mathrm{~g}$ each, $15 \mathrm{~cm}$ diameter and $5 \mathrm{~cm}$ height.

The ripening process was performed in 2 stages. In PDO registered industries, the cheeses were ripened in rooms with temperature and relative humidity controlled. The first stage was at temperature around 8 to $9^{\circ} \mathrm{C}$ and relative humidity between $92 \%$ and $97 \%$ during 8 to 10 days, followed by second period until the end of ripening at temperature around 10 to $13^{\circ} \mathrm{C}$ and relative humidity between $85 \%$ and $90 \%$. In non-PDO registered industries, the cheese-making process is more artisanal, and the production is limited to winter season. In the initial stage, the ripening was performed in a room with temperature around 12 to $13^{\circ} \mathrm{C}$ and relative humidity of $90 \%$ during 8 to 10 days, followed by a second period until the end of the ripening in a room at ambient conditions. Consequently, the temperature and relative humidity varied depending on the weather conditions, with values ranging from 8 to $18{ }^{\circ} \mathrm{C}$ and relative humidity between $65 \%$ and $95 \%$.
Two different batches by season, winter and spring, were analyzed for the PDO industries, whereas only winter was used in the non-PDO industries. Each physicochemical and microbiological assay was performed in three different cheeses by batch $(n=48)$, making each determination in triplicate.

\section{Physicochemical analysis}

The moisture content of the samples was determined by dehydration at $102 \pm 2{ }^{\circ} \mathrm{C}$ to a constant weight according to the official method of the International Organization for Standardization protocols ISO 5534:2004E. The water activity $\left(a_{\mathrm{w}}\right)$ was determined using a GBZ FA-St/1 apparatus (Scientific Instruments, Romans sur Isère, France). The $\mathrm{pH}$ was measured using a Crison mod. 2002 pH meter (Crison Instruments, Barcelona, Spain).

\section{Culture dependent analysis: microbial counts and pathogens detection}

For the isolates and microbial counts, each cheese sample $(10 \mathrm{~g})$ was placed aseptically into a sterile plastic bag with $90 \mathrm{~mL}$ 1\% peptone water (Pronadisa, Alcobendas, Madrid, Spain), and homogenized for $120 \mathrm{~s}$ in a Stomacher instrument (Lab-Blender 400 Seward Lab., London, England). The cheese homogenates were serially diluted and aliquots from each dilution were inoculated onto agar plates. Mesophilic aerobic bacteria were counted on plate count agar (PCA; Oxoid, Hampshire, UK) after incubation at $30{ }^{\circ} \mathrm{C}$ for $48 \mathrm{hr}$. Mesophilic lactobacilli and lactococci were enumerated on de Man, Rogosa and Sharpe (MRS; Oxoid) agar acidified to $\mathrm{pH} 5.6$ with acetic acid (10\%) and M17 agar (Oxoid), respectively, under $10 \% \mathrm{CO}_{2}$ atmosphere at $30{ }^{\circ} \mathrm{C}$ after 48 hr. Enterococci, typical pink or dark red colonies with a narrow whitish border, were counted on Slanetz and Bartley (SB; Oxoid) agar at $35^{\circ} \mathrm{C}$ for $48 \mathrm{hr}$. The transparent and gelatinous colonies of Leuconostoc spp. were enumerated on Mayeux, Sandine, and Elliker (MSE) agar medium (Biokar Diagnostic, Beauvais, France) at $21{ }^{\circ} \mathrm{C}$ after $72 \mathrm{hr}$. The growth of black staphylococci colonies on Baird-Parker agar (BP; Oxoid) supplemented with potassium tellurite and egg yolk emulsion was assessed after incubation at $37^{\circ} \mathrm{C}$ for $48 \mathrm{hr}$. Enterobacteria (Gram-negative and cytochrome oxidase negative), identified as rose-coloured colonies surrounded by a halo of purple precipitate, were counted on violet red bile glucose agar (VRBG; Oxoid), after incubation at $30^{\circ} \mathrm{C}$ for $24 \mathrm{hr}$. Escherichia coli were selectively grown on chromogenic tryptone bile X-glucuronide (TBX) agar (Serco, Mexico) and the typical blue-green colonies, indicating the presence of $B-D$-glucuronidase activity, were enumerated after incubation at $44{ }^{\circ} \mathrm{C}$ for $24 \mathrm{hr}$. For the enumeration of sulfite-reducing Clostridium spp., $10 \mathrm{~mL}$ aliquots of $1: 10$ diluted cheese samples were heated at $80^{\circ} \mathrm{C}$ for $10 \mathrm{~min}$ in water bath to kill vegetative forms. Then, 0.1 and 1 $\mathrm{mL}$ aliquots of the suspensions were mixed with 9.9 and $9 \mathrm{~mL}$ of sulfite-polymyxin-sulfadiazine agar (SPS, Oxoid), respectively, while a $5 \mathrm{~mL}$ aliquot was mixed with $5 \mathrm{~mL}$ of SPS agar 2X. After solidification of the media, another 2 to $3 \mathrm{~mL}$ of SPS agar was overlaid and the test tubes were incubated under anaerobic conditions at $44{ }^{\circ} \mathrm{C}$ for $72 \mathrm{hr}$. Colonies with appearances similar to black cotton wool and approximately 2 to $3 \mathrm{~mm}$ in size were counted as suspected sulfite-reducing Clostridia.

Finally, for Listeria spp. and Salmonella spp. analysis, $25 \mathrm{~g}$ of each cheese sample were placed aseptically into sterile plastic bags and homogenized in $225 \mathrm{~mL}$ of buffered peptone water and incubated at $30{ }^{\circ} \mathrm{C}$ for $24 \mathrm{hr}$. Then, Listeria spp. and Salmonella spp. were detected by ISO 11290-2:1998+A1:2004 (1998) and ISO 6785:2001 (2001), respectively. 


\section{Microbial identification of isolates by DNA sequencing analysis}

Various colonies isolated from the cheeses were identified by rRNA $16 \mathrm{~S}$ gene sequencing analysis. From each plated medium with colonies in the highest dilutions, 10 colonies were isolated at random on nutrient agar (Oxoid) and finally grown in $5 \mathrm{~mL}$ of nutrient broth (Oxoid). The genomic DNA of the pure isolates was obtained and the 16S rRNA gene sequences analyzed as described by Benito et al. (2008a, b). The sequences were compared with the EMBL/GenBank database using the BLAST algorithm. The isolates were confirmed based on the highest identity score (highest sequence homology).

For pathogens identification, presumptive Listeria spp. or Salmonella spp. isolates and $S$. aureus colonies from BP agar with a black appearance and surrounded by a clear zone and tested for catalase and coagulase activity (Staphylex, Oxoid) were confirmed by sequencing the rRNA $16 \mathrm{~S}$ gene as above. Finally, presumptive E. coli from TBX plates were transferred to tubes of brilliant green lactose bile broth (Oxoid) and incubated at 35 ${ }^{\circ} \mathrm{C}$ for 24 to $48 \mathrm{hr}$. The confirmed E. coli colonies were transferred to eosin-methylene-blue lactose sucrose agar (Oxoid) before identification by $16 \mathrm{~S}$ rRNA sequencing. Enterohemorrhagic $E$. coli serotype O157:H7 was then detected using a multiplex PCR for verotoxins as described by Fratamico, Bagi, and Pepe (2000). The primers used in the multiplex PCR and the sizes of the expected PCR products were as follows: Shiga 1 toxin $(210 \mathrm{bp})$ stx1F (5'-TGTAACTGGAAAGGTGGAGTATACA-3') and stx1R (5'GCTATTCTGAGTCAACGAAAATAAC- $3^{\prime}$ ); and Shiga 2 toxin (484 bp) stx2F (5'-GTTTTTCTTCGGTATCCTATTCC-3') and stx2R (5'-GATGCATCTCTGGTCATTGTATTAC-3'). Primers for 16S rRNA gene amplification were used as the reaction control and the verotoxin-producing E. coli CECT4267 as the positive control.

\section{Identification of bacterial community by HTS of the $16 \mathrm{~S}$ rRNA gene}

Cheese $(5 \mathrm{~g})$ was homogenized in $45 \mathrm{~mL}$ of a $2 \%$ trisodium citrate buffer (VWR, Dublin, Ireland). A $2 \mathrm{~mL}$ aliquot of the homogenate was enzymatically lysed with lysozyme $(1 \mathrm{mg} / \mathrm{mL})$, mutanolysin $(50 \mathrm{U} / \mathrm{mL})$, and proteinase $\mathrm{K}(800 \mu \mathrm{g} / \mathrm{mL})$, followed by incubation at $55^{\circ} \mathrm{C}$ for $1 \mathrm{hr}$, as previously described by Quigley, O'Sullivan, Beresford, Ross, and Fitzgerald (2011). After, the DNA was extracted using a PowerFood microbial DNA isolation kit (MoBio Laboratories Inc., Carlsbad, CA, USA).

The genomic DNA was amplified for the hypervariable V3V4 region with specific primers and further re-amplified in a limited-cycle PCR reaction to add a sequencing adaptor and dual-indexed barcodes. The initial PCR reactions were performed for each sample using 2X KAPA HiFi HotStart ready mix, $0.2 \mu \mathrm{M}$ of each PCR primer: forward primer Bakt_341F 5'-CCTACGGGNGGCWGCAG-3', and reverse primer Bakt_805R 5'-GACTACHVGGGTATCTAATCC3' (Herlemann et al., 2011; Klindworth et al., 2013) and $12.5 \mathrm{ng}$ of template DNA. The PCR conditions involved denaturation at $95{ }^{\circ} \mathrm{C}$ for $3 \mathrm{~min}$, followed by 35 cycles of $98{ }^{\circ} \mathrm{C}$ for $20 \mathrm{~s}, 55^{\circ} \mathrm{C}$ for $30 \mathrm{~s}$ and $72{ }^{\circ} \mathrm{C}$ for $30 \mathrm{~s}$ and a final extension at $72{ }^{\circ} \mathrm{C}$ for $5 \mathrm{~min}$. Negative controls were included for all amplification reactions. Second PCR reactions added the indexes and sequencing adaptors to both ends of the amplified target region by the use of 2X KAPA HiFi HotStart ready mix, $5 \mu \mathrm{L}$ of each index (i7 and i5) (Nextera XT Index Kit, Illumina, San Diego, CA) and $5 \mu \mathrm{L}$ of the first PCR product, in a total volume of $50 \mu \mathrm{L}$. The PCR conditions involved a $95^{\circ} \mathrm{C}$ denaturation for $3 \mathrm{~min}$, followed by 8 cycles at $95^{\circ} \mathrm{C}$ for $30 \mathrm{~s}, 55^{\circ} \mathrm{C}$ for $30 \mathrm{~s}$ and $72{ }^{\circ} \mathrm{C}$ for $30 \mathrm{~s}$ and a final extension at $72{ }^{\circ} \mathrm{C}$ for $5 \mathrm{~min}$. The amplicons were quantified by fluorimetry with PicoGreen dsDNA quantitation kit (Invitrogen, Life Technologies, Carlsbad, CA, USA), pooled at equimolar concentrations and pair-end sequenced with MiSeq ${ }^{\circledR}$ V3 chemistry, according to the manufacturer's instructions (Illumina, San Diego, CA, USA) at Genoinseq (Cantanhede, Portugal).

Sequenced reads were demultiplexed automatically by the Illumina ${ }^{\circledR}$ MiSeq ${ }^{\circledR}$ sequencer using the CASAVA package (Illumina, San Diego, CA, USA) and quality-filtered with PRINSEQ software (Schmieder \& Edwards, 2011) using the following parameters: 1) bases with average quality lower than Q25 in a window of 5 bases were trimmed, and 2) reads with less than 150 bases were discarded. The forward and reverse reads were merged by overlapping paired-end reads using the AdapterRemoval v2.1.5 (Schubert, Lindgreen, \& Orlando, 2016) software with default parameters. The QIIME package v1.8.0 (Caporaso et al., 2010) was used for OTU generation, taxonomic identification, sample diversity and richness indices calculation. Sample identifications were assigned to the merged reads and converted to FASTA format (split_libraries_fastq.py, QIIME). Chimeric merged reads were detected and removed using UCHIME (Edgar, Haas, Clemente, Quince, \& Knight, 2011) against the Greengenes v13.8 database (DeSantis et al., 2006) (script identify_chimeric_seqs.py, QIIME). Operational taxonomic units (OTUs) were selected at 97\% similarity threshold using the open reference strategy. First, merged reads were pre-filtered by removing sequences with a similarity lower than 60\% against the Greengenes v13.8 database (DeSantis et al., 2006). The remaining merged reads were then clustered at $97 \%$ similarity against the same databases. Merged reads that did not cluster in the previous step were de novo clustered into OTUs at $97 \%$ similarity. A representative sequence of each OTU was then selected for taxonomy assignment (pick_rep_set.py, assign_taxonomy.py; QIIME).

\section{Statistical analyses}

SPSS for Windows 21.0 (SPSS Inc Chicago, IL, USA) was used. The physicochemical and microbiological data were analyzed by a one-way analysis of variance (ANOVA). The means were separated by Tukey's honestly significant difference test.

\section{Results and Discussion}

\section{Physicochemical data}

The physicochemical characteristics of the cheeses (Table 1) revealed some differences among samples from different industries and seasons. The cheese samples had a $\mathrm{pH}$ range between 4.95-5.49, with the highest values for industry $\mathrm{V}$ and $\mathrm{A}$ in spring season. These $\mathrm{pH}$ data are in concurrence with those reported for soft cheeses (Alvarenga, Silva, Garcia, \& Sousa, 2008; Ordiales et al., 2013a; Roseiro, Wilbey, \& Barbosa, 2003). At 30 days of ripening, the moisture content of the cheeses ranged from 45.02 to $48.76 \%(p<0.05)$ for PDO industries and 39.10$51.90 \%$ for non-PDO registered industries, while the $\mathrm{a}_{\mathrm{w}}$ values were around 0.90 to 0.98 . Significant differences in moisture and $a_{w}$ between samples from industry $\mathrm{V}$ (non-PDO registered) and the rest of the industries were observed. Overall the results obtained in PDO registered industries agreed with the findings presented by Alvarenga et al. (2008) in Serpa Portuguese cheese. 
Table 1-Mean values of $\mathrm{pH}$, moisture and $a_{\mathrm{w}}$ values in cheese samples.

\begin{tabular}{|c|c|c|c|c|c|}
\hline \multicolumn{3}{|c|}{ Serpa Cheese } & \multicolumn{3}{|c|}{ Physicochemical parameters } \\
\hline Season & PDO registered & Industries & $\begin{array}{c}\mathrm{pH} \\
\text { Mean } \pm \mathrm{SD}^{*}\end{array}$ & $\begin{array}{c}\text { Moisture (\%) } \\
\text { Mean } \pm \text { SD }\end{array}$ & $\stackrel{a_{\mathrm{w}}}{\text { Mean }} \pm$ SD \\
\hline \multirow[t]{5}{*}{ Winter } & Yes & A & $5.08 \pm 0.09^{\mathrm{a}}$ & $48.76 \pm 0.62^{\mathrm{a}}$ & $0.96 \pm 0.02^{\mathrm{a}}$ \\
\hline & & $\mathrm{C}$ & $5.03 \pm 0.03^{\mathrm{a}}$ & $47.71 \pm 1.53^{\mathrm{ab}}$ & $0.98 \pm 0.01^{\mathrm{a}}$ \\
\hline & & G & $4,95 \pm 0.01^{\mathrm{a}}$ & $47.21 \pm 0.96^{\mathrm{ab}}$ & $0.97 \pm 0.03^{\mathrm{a}}$ \\
\hline & No & $\mathrm{V}$ & $5.49 \pm 0.04^{c}$ & $39.10 \pm 1.34^{c}$ & $0.90 \pm 0.03^{\mathrm{b}}$ \\
\hline & & B & $5.02 \pm 0.09^{\mathrm{a}}$ & $51.90 \pm 0.99^{\mathrm{d}}$ & $0.96 \pm 0.01^{\mathrm{a}}$ \\
\hline \multirow[t]{3}{*}{ Spring } & Yes & A & $5.48 \pm 0.04^{\mathrm{c}}$ & $47.25 \pm 1.37^{\mathrm{ab}}$ & $0.98 \pm 0.01^{\mathrm{a}}$ \\
\hline & & C & $4.99 \pm 0.16^{\mathrm{a}}$ & $45.02 \pm 3.69^{\mathrm{a}}$ & $0.98 \pm 0.01^{\mathrm{a}}$ \\
\hline & & G & $5.36 \pm 0.10^{\mathrm{b}}$ & $46.60 \pm 1.17^{\mathrm{ab}}$ & $0.98 \pm 0.01^{\mathrm{a}}$ \\
\hline$P$ values & & & 0.000 & 0.038 & 0.046 \\
\hline
\end{tabular}

${ }^{\mathrm{a}, \mathrm{b}, \mathrm{c}}$ For a given determination (column), values with different superscript numbers are significantly different $(P<0.05)$.

Table 2-Mean values of the microbiological counts $(\log \mathrm{cfu} / \mathrm{g})$ in Serpa cheese from different PDO and non-PDO registered industries.

\begin{tabular}{|c|c|c|c|c|c|c|c|c|}
\hline \multirow{3}{*}{$\begin{array}{l}\text { Season } \\
\text { PDO registered } \\
\text { Industries }\end{array}$} & \multicolumn{5}{|c|}{ Winter } & \multirow{2}{*}{\multicolumn{3}{|c|}{$\begin{array}{c}\text { Spring } \\
\text { Yes }\end{array}$}} \\
\hline & \multicolumn{3}{|c|}{ Yes } & \multicolumn{2}{|c|}{ No } & & & \\
\hline & A & C & G & $\mathbf{V}$ & B & $\mathbf{A}$ & C & G \\
\hline Mesophilic aerobic bacteria (PCA ${ }^{*}$ ) & 8.52 & 8.65 & 8.61 & 8.20 & 8.53 & 8.51 & 8.59 & 8.92 \\
\hline Lactobacilli (MRS) & $8.03^{\mathrm{b}}$ & $8.53^{\mathrm{bc}}$ & $9.54^{\mathrm{d}}$ & $7.81^{\mathrm{b}}$ & $7.33^{\mathrm{a}}$ & $8.19^{\mathrm{bc}}$ & $8.32^{\mathrm{bc}}$ & $8.63^{\mathrm{b}}$ \\
\hline Lactococci (M17) & $8.23^{\mathrm{ab}}$ & $8.44^{\mathrm{ab}}$ & $8.56^{\mathrm{bc}}$ & $8.46^{\mathrm{ab}}$ & $8.02^{\mathrm{a}}$ & $8.04^{\mathrm{a}}$ & $8.57^{\mathrm{bc}}$ & $9.01^{\mathrm{d}}$ \\
\hline Leuconostoc (MSE) & $2.24^{\mathrm{b}}$ & $2.83^{\mathrm{b}}$ & $7.96^{\mathrm{c}}$ & n.d.**a & $7.21^{\mathrm{c}}$ & $7.01^{c}$ & $7.82^{c}$ & $7.20^{c}$ \\
\hline Enterococci (SB) & $6.54^{\mathrm{ab}}$ & $7.15^{\mathrm{c}}$ & $6.32^{\mathrm{a}}$ & $7.65^{\mathrm{d}}$ & $6.66^{\mathrm{ab}}$ & $6.83^{\mathrm{bc}}$ & $7.04^{\mathrm{c}}$ & $6.51^{\mathrm{ab}}$ \\
\hline Staphylococci (BP) & n.d. ${ }^{a}$ & n.d. ${ }^{\mathrm{a}}$ & n.d. ${ }^{\mathrm{a}}$ & $3.04^{\mathrm{b}}$ & n.d. ${ }^{\mathrm{a}}$ & $6.01^{\mathrm{b}}$ & $4.78^{b}$ & $2.18^{\mathrm{a}}$ \\
\hline Staphylococcus aureus (BP) & n.d. ${ }^{\mathrm{a}}$ & n.d. ${ }^{\mathrm{a}}$ & n.d. ${ }^{\mathrm{a}}$ & $3.04^{\mathrm{b}}$ & n.d. ${ }^{\mathrm{a}}$ & n.d. ${ }^{\mathrm{a}}$ & n.d. ${ }^{\mathrm{a}}$ & n.d. ${ }^{\mathrm{a}}$ \\
\hline Enterobacteria (VRBG) & $7.28^{\mathrm{b}}$ & $5.20^{\mathrm{b}}$ & $6.33^{\mathrm{b}}$ & $5.97^{\mathrm{b}}$ & $5.30^{\mathrm{b}}$ & $2.55^{\mathrm{a}}$ & $6.47^{\mathrm{b}}$ & $6.89^{\mathrm{b}}$ \\
\hline Escherichia coli (TBX) & $3.93^{\mathrm{d}}$ & $2.20^{\mathrm{b}}$ & $2.44^{\mathrm{bc}}$ & $3.88^{\mathrm{d}}$ & $3.12^{\mathrm{abc}}$ & $0.86^{\mathrm{a}}$ & $3.55^{\mathrm{cd}}$ & $3.14^{\mathrm{abc}}$ \\
\hline Sulfite-reducing Clostridia (SPS) & n.d. ${ }^{a}$ & n.d. ${ }^{a}$ & $1.88^{\mathrm{b}}$ & n.d. ${ }^{a}$ & n.d. ${ }^{a}$ & $0.88^{\mathrm{b}}$ & n.d. ${ }^{\mathrm{a}}$ & $0.83^{b}$ \\
\hline
\end{tabular}

a,b,c,d For a given determination, values (row) with different superscript letters are significantly different $(P<0.05)$

*PCA: Plate count agar; MRS: de Man, Rogosa and Sharpe Agar; M17: M17 agar; MSE: Mayeux, Sandine and Elliker agar; SB: Slanetz and Bartley agar; BP: Baird-Parker agar; *PCA: Plate count agar; MRS: de Man, Rogosa and Sharpe Agar; M17: M17 agar; MSE: Mayeux, Sandine and Elliker agar; SB: Slanetz a
VRBG: Violet Red Bile Glucose agar; TBX: chromogenic tryptone bile X-glucuronide agar; SPS: sulfite-polymyxin-sulfadiazine agar.

**n.d. not detected.

Microbial counts and identifications. The microbiological counts revealed some significant differences among cheeses from different industries and seasons (Table 2). Total aerobic bacteria counts ranged from 8.20 to $8.92 \mathrm{log} \mathrm{cfu} / \mathrm{g}$ at the end of ripening process. Overall, the microbiota of raw milk cheese without the addition of starter is commonly dominated by a limited number of $\mathrm{LAB}$ genera, which have important roles in the organoleptic properties of artisanal cheeses (Feutry, Oneca, Berthier, \& Torre, 2012; Ordiales et al., 2013a, b). The presumptive lactobacilli ranged from 7.33 to $9.54 \log \mathrm{cfu} / \mathrm{g}$, with the lower counts among the samples for non-PDO industries, $\mathrm{V}$ and $\mathrm{B}$ (7.33 and $7.81 \mathrm{log}$ $\mathrm{cfu} / \mathrm{g}$ respectively). The counts of lactococci were similar to lactobacilli, whereas the levels of Leuconostoc spp. were lower in all samples. This last LAB group showed the most variation between the industries. The enterococci population was also detected at a considerable level, with counts ranging from 6.32 to $7.65 \mathrm{log}$ $\mathrm{cfu} / \mathrm{g}$. The presence of high numbers of enterococci is typical of artisan raw milk cheese, which, due to their ubiquitous presence, can easily contaminate the raw milk during its collection or at various stages of cheese making, due to poor manufacturing practices (Ordiales et al., 2013a, b; Ortigosa et al., 2008). However, they are considered a common member of cheese microbiota, with important influence in the ripening process (Moreno, Sarantinopoulos, Tsakalidou, \& De Vuyst, 2006).
For secondary microbiota, staphylococci were detected at a significantly lower level in winter cheeses compared to the spring samples. The staphylococci population is common in artisanal cheese with high variability in the counts (Galan, Cabezas, \& Fernández-Salguero, 2012; Ordiales et al., 2013a).

Finally, the enterobacteria counts were between 5.20 and $7.28 \mathrm{log} \mathrm{cfu} / \mathrm{g}$ with no significant differences between the industries, except for industry A in the spring, which scored statistically lower counts at $2.55 \mathrm{log} \mathrm{cfu} / \mathrm{g}$. A high level of enterobacteria is usually considered an indication of poor hygienic practices. However, the aforementioned values are in agreement with the range found by other workers for similar soft cheeses at around 30 days of ripening (Ordiales et al., 2013a, b; Tavaria \& Malcata, 1998). Importantly, the presence of enterobacteria in high number at the end of the ripening may also be involved in the development of the sensory properties of the final cheese. Conversely, some species of this microbial group are considered spoilage organisms or even may be human pathogens, such as E. coli or Salmonella spp. Therefore, the level of E. coli was also investigated. Although much lower counts were detected, E. coli followed a similar tendency to the enterobacteria counts between the industries, with industry A in spring displaying the lowest counts.

The isolates from the PCA, MRS, M17, MSE, and SB plates were further investigated for their identification at the species level 
Table 3-Identification of the isolates from PCA, MRS, M17, MSE, and SB plates and percent of distribution of each species by industry.

\begin{tabular}{|c|c|c|c|c|c|c|c|c|}
\hline \multirow{4}{*}{$\begin{array}{l}\text { Identification } \\
\text { Sequencing of } 16 \mathrm{~S} \text { rRNA gene Species-Accession no. ( } \% \text { identity) }\end{array}$} & \multicolumn{8}{|c|}{ Industry } \\
\hline & \multicolumn{5}{|c|}{ Winter } & \multirow{2}{*}{\multicolumn{3}{|c|}{$\frac{\text { Spring }}{\text { PDO }}$}} \\
\hline & \multicolumn{3}{|c|}{ PDO } & \multicolumn{2}{|c|}{ Non-PDO } & & & \\
\hline & A & $\mathrm{C}$ & G & $\mathbf{V}$ & B & A & $\mathrm{C}$ & G \\
\hline & \multicolumn{8}{|c|}{$\%$ of isolates on PCA* } \\
\hline Lb. paracasei - CP013921.1/ Lb. casei - /KT897918.1 (100\%) & 26.6 & 71.4 & 61.8 & 30.1 & & 47.2 & 35.4 & 32.5 \\
\hline Lb. plantarum - KT946604.1 (100\%) & 26.6 & & 12.4 & & 16.7 & & & 32.5 \\
\hline Lb. brevis - KP793171.1 (100\%) & & & & 15.1 & 50.2 & & 6.4 & \\
\hline L. mesenteroides - KP742818.1 (99\%) & & & & & & 5.9 & 30.1 & 8.1 \\
\hline E. faecalis - KU321632.1 (100\%) & 17.8 & 5.1 & & & 8.3 & 6 & 5.9 & \\
\hline E. faecium - CP014449.1 (100\%) & & & & & & 17.8 & & \\
\hline E. hirae - LC122277.1 (100\%) & & & & 15.1 & & & & \\
\hline Hafnia alvei - KT767875.1 (100\%) & 29.2 & 23.6 & 25.9 & 21.7 & 13.5 & 23.1 & 23.1 & 26.8 \\
\hline \multirow[t]{2}{*}{ Escherichia coli- CP015076.1 (99\%) } & & & & 18.1 & 11.3 & & & \\
\hline & \multicolumn{8}{|c|}{$\%$ of isolates on MRS } \\
\hline Lb. paracasei-CP013921.1/ Lb. casei - /KT897918.1 (100\%) & 37.5 & 100 & 71.4 & 40 & & 61.3 & 50 & 40 \\
\hline Lb. plantarum - KT946604.1 (100\%) & 37.5 & & 14.3 & & 22.2 & & & 40 \\
\hline Lb. pentosus - KU945826.1 (100\%) & & & 14.3 & & & & & \\
\hline Lb. curvatus - KT763326.1 (100\%) & & & & & & & & 10 \\
\hline Lb. brevis - KP793171.1 (100\%) & & & & 20 & 66.7 & & 8.3 & \\
\hline L. mesenteroides - KP742818.1 (99\%) & & & & & & 7.7 & 41.7 & 10 \\
\hline E. faecalis - KU321632.1 (100\%) & 12.5 & & & & 11.1 & 7.7 & & \\
\hline E. faecium - СР014449.1 (100\%) & 12.5 & & & 20 & & 23.2 & & \\
\hline \multirow[t]{2}{*}{ E. hirae - LC122277.1 (99\%) } & & & & 20 & & & & \\
\hline & \multicolumn{8}{|c|}{$\%$ of isolates on M17 } \\
\hline Lb. paracasei - CP013921.1/Lb. casei - /KT897918.1 (100\%) & & & & & & 50 & 14.3 & \\
\hline Lb. plantarum - LC125266.1 (100\%) & & & & & & & 14.3 & \\
\hline Lb. brevis - KT757228.1 (100\%) & 25 & & & & & & & \\
\hline L. mesenteroides - KP742818.1 (99\%) & & & 100 & & & 25 & 57.1 & 100 \\
\hline Lc. lactis - KT757263.1 (100\%) & & & & & & & 14.3 & \\
\hline E. faecalis - KU321632.1 (100\%) & 75 & 50 & & 20 & 50 & 25 & & \\
\hline E. faecium - СР014449.1 (100\%) & & & & 40 & & & & \\
\hline \multirow[t]{2}{*}{ E. hirae - LC122277.1 (100\%) } & & 50 & & 40 & 50 & & & \\
\hline & \multicolumn{8}{|c|}{$\%$ of isolates on MSE } \\
\hline \multirow[t]{2}{*}{ L. mesenteroides- KP742818.1 (99\%) } & 100 & 100 & 100 & 100 & 100 & 100 & 100 & 100 \\
\hline & \multicolumn{8}{|c|}{$\%$ of isolates on $\mathrm{SB}$} \\
\hline E. faecalis - KU321632.1 (100\%) & 87.5 & 71.4 & & & 100 & 87.5 & 100 & 57.2 \\
\hline E. faecium - CP014449.1 (100\%) & & 14.3 & & & & & & 42.8 \\
\hline E. hirae - LC122277.1 (100\%) & 12.5 & 14.3 & 16.7 & 75 & & & & \\
\hline
\end{tabular}

*PCA: Plate count agar; MRS: de Man, Rogosa and Sharpe Agar; M17: M17 agar; MSE: Mayeux, Sandine and Elliker agar; SB: Slanetz and Bartley agar.

Table 4-Identification of the isolates from BP, VRBG, and TBX plates and percent of distribution of each species by industry.

\begin{tabular}{|c|c|c|c|c|c|c|c|c|}
\hline \multirow[b]{4}{*}{$\begin{array}{l}\text { Sequencing of } 16 \mathrm{~S} \text { rRNA gene } \\
\text { Species-Accession no. ( } \% \text { identity) }\end{array}$} & \multicolumn{8}{|c|}{ Industry } \\
\hline & \multicolumn{5}{|c|}{ Winter } & \multirow{2}{*}{\multicolumn{3}{|c|}{$\begin{array}{c}\text { Spring } \\
\text { PDO }\end{array}$}} \\
\hline & \multicolumn{3}{|c|}{ PDO } & \multicolumn{2}{|c|}{ Non-PDO } & & & \\
\hline & $\mathbf{A}$ & $\mathrm{C}$ & G & $\mathbf{V}$ & $\mathbf{B}$ & $\mathbf{A}$ & C & G \\
\hline & \multicolumn{8}{|c|}{$\%$ of isolates on $\mathrm{BP}^{*}$} \\
\hline S. epidermidis - KT989845.1 (100\%) & & & & & & 25 & 100 & \\
\hline S. caprae - KT387321.1 (100\%) & & & & & & 12.5 & & \\
\hline S. hominis - LN774575.1 (100\%) & & & & & & 12.5 & & \\
\hline S. warneri - KC139448.1 (100\%) & & & & & & 37.5 & & 33.3 \\
\hline S. simulans - CP014016.1 (100\%) & & & & & & 12.5 & & \\
\hline S. cohnii - KX023361.1 (100\%) & & & & & & & & 66.7 \\
\hline \multirow[t]{2}{*}{ S. aureus - CP015173.1 (100\%) } & \multirow{2}{*}{\multicolumn{8}{|c|}{$\begin{array}{c}100 \\
\% \text { of isolates on VRBG }\end{array}$}} \\
\hline & & & & & & & & \\
\hline H. alvei - KT767875.1 (100\%) & 100 & 100 & 100 & 30 & 60 & 100 & 100 & 100 \\
\hline E. coli-CP015076.1 (99\%) & & & & 60 & 40 & & & \\
\hline \multirow{2}{*}{ K. oxytoca-KU761531.1 (100\%) } & & & & 10 & & & & \\
\hline & \multicolumn{8}{|c|}{$\%$ of isolates on TBX } \\
\hline E. coli-CP015076.1 (100\%) & 100 & 100 & 100 & 100 & 100 & 100 & 100 & 100 \\
\hline
\end{tabular}

*BP: Baird-Parker agar; VRBG: Violet Red Bile Glucose agar; TBX: chromogenic tryptone bile X-glucuronide agar. 
(Table 3). Counts on the PCA medium provided a guide to the prevalence of live bacteria in the final cheese. The microorganisms identified in the PCA medium mainly corresponded to LAB and to a lesser extent, enterobacteria. Lactobacillus paracasei/Lb. casei were the main species in cheese samples from PDO industries (A, $\mathrm{C}$ and $\mathrm{G}$ ) in both seasons. Lb. casei and $\mathrm{Lb}$. paracasei are closely related species and, therefore, difficult to distinguish, with $99.4 \%$ similarity (Öztürk \& Meterelliyöz, 2015). In cheeses from nonPDO registered industries, $L b$. brevis and $L b$. paracasei/casei were the dominant species in industries $\mathrm{B}$ and $\mathrm{V}$, respectively. Other LAB identified were Lb. plantarum, Leuconostoc mesenteroides, only identified in spring season, and species belonging to the genus Enterococcus. E. faecium appeared in cheeses from industries A and $\mathrm{V}$, while E. faecalis has a higher prevalence in A and B. These genera and species are among the most common LAB found in raw milk cheese (Feutry et al., 2012; Fuka et al., 2013; Ordiales et al., 2013a; Picon, Garde, Ávila, \& Nuñez, 2016). Finally, some species from the Enterobacteriaceae family were detected, which contributed to around 20 to $40 \%$ of the total isolates identified. The species, Hafnia alvei, was identified at around 20 to $30 \%$ in all the industries. This species has demonstrated its ability to survive during the ripening process of soft cheese and other types of cheese with a long maturation process (Abriouel et al., 2008; Coton et al., 2012; Ordiales et al., 2013a; Tabla et al., 2016). Moreover, it is known to positively contribute to the aromatic properties of cheeses (Irlinger et al., 2012). The most disturbing was the presence of $E$. coli in the final product at appreciable level, particularly those obtained from industries $\mathrm{V}$ and $\mathrm{B}$ (both nonPDO registered industries), which may be due to poor milking hygiene or poor hygienic processing as consequence of different manufacturing practices suggested by PDO "Cheese Serpa".

These results differ slightly from the results obtained with HTS (Figure 1). During whole cheese processing, the predominant bacteria comprised Lactococcus, Lactobacillus, and Leuconostoc genera. Most of the identifications matched with those obtained in PCA, except for Lactococcus. Studies to assess the persistence and viability of this microorganism throughout manufacturing and ripening of cheeses have been done (Ruggirello, Cocolin, \& Dolci, 2016; Ruggirello, Dolci, \& Cocolin, 2014). The authors observed that at the end of ripening, lactococci were detected at a minimal amount and this discrepancy was explained with the knowledge that during the ripening process, lactococci enter in a stressed physiological state (viable not culturable, VNC), which might cause their inability to grow on synthetic medium despite their viability in the cheese matrix.

The identification of microorganisms isolated from the specific media MRS, M17, MSE and SB for various LAB genera is shown in Table 3. In MRS, corresponding mainly to Lactobacillus spp., $L b$. paracasei/Lb. casei was the most common species in this medium, followed by sporadic identification of $L b$. platarum, $L b$. brevis, $L b$. pentosus and $L b$ curvatus. In particular, $L b$. brevis was present at a relatively high percentage in samples from $\mathrm{V}$ and $\mathrm{B}$ (both nonPDO registered industries). L. mesenteroides, E. faecalis, E. faecium and $E$. hirae were also identified in MRS agar but not in all samples. L. mesenteroides was also detected in PCA agar but was also only associated with spring season samples.

In M17, only Lactococcus lactis was detected in samples from industry C. This is in discordance with the HTS results (Figure 1B), where Lactococcus was the most abundant genera in the cheeses. The viability of Lactococcus at the end of ripening is minimal because they succumb to a stressed physiological state during the ripening process (Ruggirello et al., 2014, 2016). On the other hand, it has been reported that M17 medium it is not such a selectivity for lactococci species growth (Ruggirello et al., 2014).

All the isolates identified in MSE and SB medium corresponded to Leuconostoc spp. and Enterococcus spp., respectively, showing both media were highly selective for enumerating these genera of LAB (Table 3).

Leuconostoc spp. isolates were found in all industries and were identified as L. mesenteroides (Table 3 ). This species is usually found as a subdominant $\mathrm{LAB}$ species with raw milk cheese (Aquilanti et al., 2011; Fuka et al., 2013; Picon et al., 2016) and, alongside Leucnostoc lactis, is the most relevant species of this genus in the dairy industry (Hemme \& Foucaud-Scheunemann, 2004). Although these species grow poorly in milk, they are more competitive in the late stage of the cheese ripening process. In particular, it is known that these bacteria contribute to the peculiar aroma of traditional cheeses, mainly due to their ability to metabolize citrate and lactate (McSweeney \& Sousa, 2000). Additionally, they may influence the texture of cheese by the synthesis of dextrans. These valuable technological properties are the reason some researchers have considered them as starters for cheese manufacture (Alegría, Delgado, Flórez, \& Mayo, 2013; Nieto-Arribas, Seseña, Poveda, Palop, \& Cabezas, 2010) and may positively influence the organoleptic properties in Serpa cheese from spring season.

The enterococci population was dominated by E. faecalis, followed by E. faecium and E. hirae, which was only identified in winter samples and was the predominant species in industry $\mathrm{V}$ (Table 3). E. faecalis and E. faecium are common enterococci species found in raw milk cheese, whereas E. hirae is more sporadically present at an important level (Feutry et al., 2012; Ordiales et al., 2013a). Among the LAB genera, enterococci raise some controversy because some members, particularly E. faecalis, have been linked to various virulence factors, antibiotic resistance and gene transfer mechanisms related to human pathogenesis (Moreno et al., 2006). Moreover, they also present important tyrosine decarboxylase activity, responsible for tyramine accumulation in cheese (Picon et al., 2016). However, in many artisanal cheeses, their presence has been correlated with a positive contribution to the ripening process, influencing the development of the typical organoleptic properties, and inhibiting foodborne pathogens by producing the bacteriocins, enterocins (Giraffa, 2003; Ordiales et al., 2013b).

Table 4 shows the species identified in the BP, VRBGA and TBX plates. S. aureus is a foodborne pathogen and was the unique species identified in the samples originating from industry $\mathrm{V}$, which is a non-PDO registered. Staphylococcus epidermidis, S. warneri and $S$. cohnii were mainly identified in cheeses prepared during spring. Staphylococcus spp. has been detected in most cheese varieties as a major component of the secondary flora that remains throughout ripening, probably due to their resistance to salt and dehydration (Little et al., 2008; Ordiales et al., 2013a).

The predominance of the Enterobacteriaceae family was also observed by HTS analysis during the ripening process (Figure 1A). Enterobacteriaceae have frequently been found during cheese manufacture (Coton et al., 2012; Ordiales et al., 2013a). The enterobacteria identified were mainly dominated by $H$. alvei, except for industries $\mathrm{V}$ and $\mathrm{B}$ (both non-PDO registered). For these two industries $E$. coli was also identified at a high level (Table 4), some strains of this species are considerate important foodborne pathogens. $H$. alvei has often been described as the dominant Gram-negative bacteria in cheeses (Abriouel et al., 2008; Coton et al., 2012; Ordiales et al., 2013a). These bacteria have been shown to display high proteolytic activities, which 


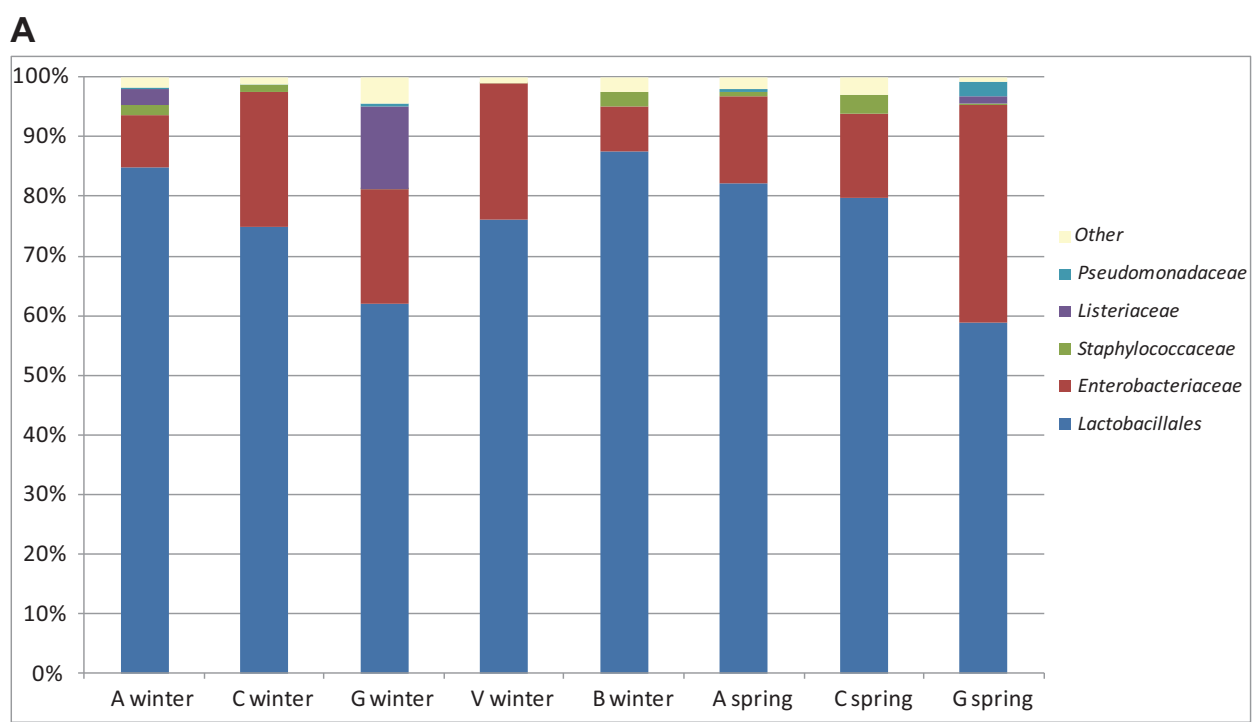

\section{B}

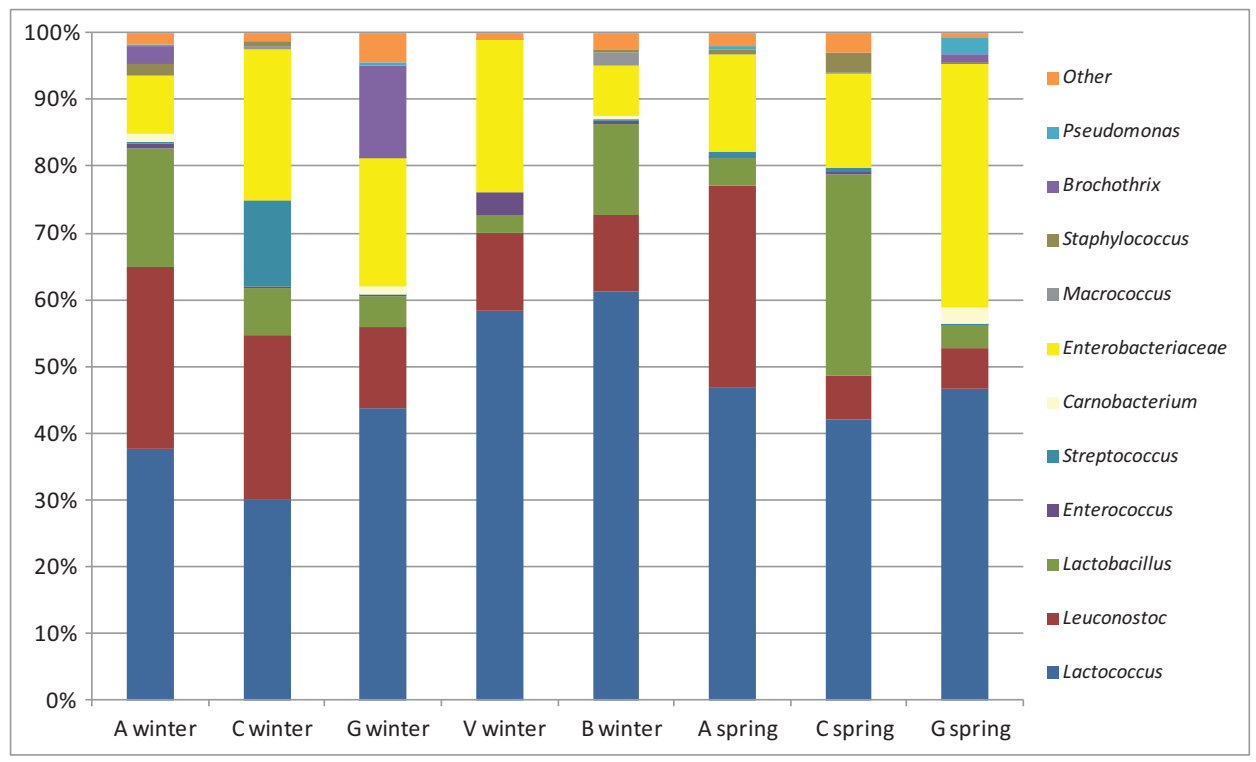

Figure 1-Mean relative abundance of bacteria in cheeses from different industries (capital letters) analyzed in two different seasons (winter and spring) using high-throughput sequencing of the 16S rRNA gene. (A) at the family level; (B) at the genus level.

could affect the sensory quality of cheese, such as creamy cheeses (Ordiales et al., 2013b).

\section{Pathogen detection}

The most relevant foodborne pathogens in raw milk cheeses, Listeria monocytogenes, Salmonella spp. and enterohemorrhagic E. coli were not detected in any of the cheese samples after 30 days of ripening. The absence of these pathogens in the cheese indicates the safety quality of the final product. The bacterial populations at the end of the ripening time depend on the adaptation of the microorganisms to the stress conditions found during the maturation process, such as salt concentration, $\mathrm{pH}$ decrease and competitive interaction with the microbiota present (Donnelly, 2004).

E. coli was found in all cheese samples at 30 days of ripening (Table 4) and all the isolates from the TBX medium were identified as E. coli by sequencing. This could have been due to the use of contaminated milk. E. coli is also used as an indicator of direct or indirect fecal contamination of foods, suggesting possible presence of enteric pathogens. In cheese, the presence of E. coli may indicate poor hygiene conditions (Kornaki \& Johnson, 2001). Little et al. (2008) found initial levels of E. coli ranging from 1.1 $\times 10^{5}$ to $4.6 \times 10^{6} \mathrm{cfu} / \mathrm{g}$ in raw milk cheese, and Ordiales et al. (2013a) found E. coli at 30 days of ripening in soft cheese "Torta del Casar," but these were not detected at the end of ripening process (60 days). So, these reports highlight the importance of the ripening period in raw milk cheese to ensure the safety of the final product, particularly considering the ability of some pathogens, such as E. coli $\mathrm{O} 157: \mathrm{H} 7$ and Listeria monocytogenes to tolerate periods of similar maturity to Serpa cheese (Almeida et al., 2007; Montet et al., 2009). Although no relevant foodborne pathogens were detected at 30 days, the E. coli level found in all samples at the end of the ripening (Table 2), highlighted its identification among 
the dominants species on PCA agar on non-PDO industries (Table 3), suggests that a longer period, close to 60 days of ripening, would be recommended.

$S$. aureus was only found in cheeses from industry V (non-PDO registered) (Table 3). In raw milk cheese, $S$. aureus contamination can be caused by raw milk produced by animals suffering from mastitis, contaminated milk tank, and poor hygiene practices or the cheese handlers who are $S$. aureus carriers (Guerreiro, Velez, Alvarenga, Matos, \& Duarte, 2013; Rola, Czubkowska, KorpysaDzirba, \& Osek, 2016). S. aureus has been reported in cheese made from raw milk with a higher incidence than other foodborne pathogens (Little et al., 2008; Ordiales et al., 2013a). However, although $S$. aureus can produce an enterotoxin that causes illness, high numbers of the organism are necessary to produce the toxin in sufficient quantities to be a threat to public health (Le Loir, Baron, \& Gautier, 2003). S. aureus can grow during cheese processing, but once $a_{\mathrm{w}}$ and $\mathrm{pH}$ are decreased, its growth is generally inhibited (Stewart et al., 2002)

Sulfite-reducing clostridia are widespread in the environment and can contaminate milk and cheese. They were detected in some cheese samples from industries $\mathrm{G}$ and A, but at low levels (Table 2). Clostridia include pathogenic representatives, such as Clostridium perfringens, C. botulinum, C. difficile, and C. tetani, as well as the spoilage species, C. tyrobutyricum, which is the main cause of the late-blowing defect in cheese, responsible for relevant financial losses in the dairy industry (Brändle, Domig, \& Kneifel, 2016).

\section{Conclusions}

The data reported in this study showed higher differences among the identified microorganisms isolated from cheeses obtained from PDO and non-PDO industries. Hence, the production regulation gives guarantees of standardization to the product. The microorganisms identified at the end of ripening were $\mathrm{LAB}$ and to a lesser extent, enterobacteria, with $L b$. paracasei/Lb. casei being the main species in cheese from PDO industries, while in non-PDO industries Lb.brevis was also identified at high level. However, by culture independent methodology (HTS), the predominating genera were mainly Lactococcus, followed by Lactobacillus, and Leuconostoc genus. Finally, although high level of enterobacteria were found, the main foodborne pathogens, L. monocytogenes, Salmonella spp. and enterohemorrhagic E. coli were not detected in cheese samples at the end of maturation, which guarantee the microbiological safety of the final product. Moreover, the study of technological and functional properties of autochthonous strains of lactic acid bacteria could be also an important tool, starter cultures to control the ripening process and ensure the final quality and safety of the cheese.

\section{Acknowledgments}

The authors are grateful to $\mathrm{M}$. Cabrero and J. Barneto for technical assistance, PDO "Serpa Cheese" for technical support, and Genoinseq (Cantanhede, Portugal) for high-throughput sequencing analysis. This work was funded by grant GR15166 from Junta Extremadura Government Portuguese Ministry of Agriculture and Rural Development (Grant no PDR2020-101-031017), European Agricultural Fund for Rural Development (EAFRD) and European Regional Development Fund (ERDF).

\section{Authors' Contributions}

Maria Teresa P. Gonçalves carried out experiments, interpreted the results and drafted the manuscript. María José Benito designed the study, interpreted the results and wrote the manuscript.
María de Guía Córdoba collaborated in designing experiments and drafted the manuscript. Conceição Egas developed highthroughput sequencing analysis and drafted the manuscript. Almudena V. Merchán carried out experiments and participated in data analysis. Ana I. Galván carried out experiments and participated in data analysis. Santiago Ruiz-Moyano participated in designing the study and experiments, interpreted results and drafted the manuscript.

\section{References}

Abriouel, H., Martín-Platero, A., Maqueda, M., Valdivia, E., \& Martínez-Bueno, M. (2008) Biodiversity of the microbial community in a Spanish farmhouse cheese as revealed by culturedependent and culture-independent methods. International Journal of Food Microbiology, 127, 200-208. https://doi.org/10.1016/j.ijfoodmicro.2008.07.004

Alegría, Á., Delgado, S., Flórez, A. B., \& Mayo, B. (2013). Identification, typing, and functional characterization of Leuconostoc spp. strains from traditional, starter-free cheeses. Dairy Science \& Technology, 93, 657-673. https://doi.org/10.1007/s13594-013-0128-3

Alessandria, V., Ferrocino, I., De Filippis, F., Fontana, M., Rantsiou, K., Ercolini, D., \& Cocolin, L. (2016). Microbiota of an Italian Grana like cheese during manufacture and ripening unraveled by $16 \mathrm{~S}$ rRNA-based approaches. Applied and Environmental Microbiology, 82, 3988-3995. https://doi.org/10.1128/AEM.00999-16

Almeida, G., Figueiredo, A., Rôla, M., Barros, R. M., Gibbs, P., Hogg, T., \& Teixeira, P. (2007). Microbiological characterization of randomly selected Portuguese raw milk cheeses with reference to food safety. Journal of Food Protection, 70, 1710-1716. https://doi.org/10.4315/0362-028X-70.7.1710

Alvarenga, N., Silva, P., Garcia, J. R., \& Sousa, I. (2008). Estimation of Serpa cheese ripening time using multiple linear regression (MLR) considering rheological, physical and chemical data. Journal of Dairy Research, 75, 233-239. https://doi.org/10.1017/S0022029908003191

Alvarenga, N., Canada, J., \& Sousa, I. (2011). Effect of freezing on the rheological, chemical and colour properties of Serpa cheese. Journal of Dairy Research, 78, 80-87. https://doi.org/10.1017/S0022029910000841

Aquilanti, L., Babini, V., Santarelli, S., Osimani, A., Petruzzelli, A., \& Clementi, F. (2011) Bacterial dynamics in a raw cow's milk Caciotta cheese manufactured with aqueous extract of Cynara cardunculus dried flowers. Letters in Applied Microbiology, 52, 651-659. https://doi.org/10.1111/j.1472-765X.2011.03053.x

Benito, M. J., Serradilla, M. J., Martín, A., Aranda, E., Hernández, A., \& Córdoba, M. G. (2008a) Differentiation of Staphylococci from Iberian dry fermented sausages by protein fingerprinting. Food Microbiology, 25, 676-682. https://doi.org/10.1016/j.fm.2008.03.007

Benito, M. J., Serradilla, M. J., Ruiz-Moyano, S., Martín, A., Pérez-Nevado, F., \& Córdoba, M. G. (2008b). Rapid differentiation of lactic acid bacteria from autochthonous fermentation of Iberian dry-fermented sausages. Meat Science, 80, 656-661. https://doi.org/10.1016/j.meatsci.2008.03.002

Bokulich, N. A., \& Mills, D. A. (2012). Next-generation approaches to the microbial ecology of food fermentations. BMB Reports, 45, 377-389. https://doi.org/ 10.5483/BMBRep.2012.45.7.148

Bokulich, N. A., \& Mills, D. A. (2013). Facility-specific "house," microbiome drives microbial landscapes of artisan cheesemaking plants. Applied and Environmental Microbiology, 79, 52145223. https://doi.org/10.1128/AEM.00934-13.

Brändle, J., Domig, K. J., \& Kneifel, W. (2016). Relevance and analysis of butyric acid producing clostridia in milk and cheese. Food Control, 67, 96-113. https://doi.org/ 10.1016/j.foodcont.2016.02.038

Caporaso, J. G., Kuczynski, J., Stombaugh, J., Bittinger, K., Bushman, F. D., Costello, E. K., Gordon, J. I. (2010). QIIME allows analysis of high-throughput community sequencing data. Nature Methods, 7, 335-336. https://doi.org/10.1038/nmeth.f.303

Coton, M., Delbés-Paus, C., Irlinger, F., Desmasures, N., Le Fleche, A., Stahl, V., . . Coton, E. (2012). Biodiversity and assessment of potential risk factors of Gram-negative isolates associated with French cheeses. Food Microbiology, 29, 88-98. https://doi.org/10.1016/j.fm.2011.08.020 DeSantis, T. Z., Hugenholtz, P., Larsen, N., Rojas, M., Brodie, E. L., Keller, K. Andersen, G. L. (2006). Greengenes, a chimera-checked 16S rRNA gene database and workbench compatible with ARB. Applied and Environmental Microbiology, 72, 5069-5072. https://doi.org/10.1128/AEM.03006-05

Donnelly, C. W. (2004). Growth and survival of microbial pathogens in cheese. In P. F. Fox, P. L. H. McSweeney, T. M. Cogan, \& T. P. Guinee (Eds.), Cheese: Chemistry, physics and microbiology general aspects (pp. 541-559). London, UK: Elsevier. Academic Press.

Dos Santos, M. T. P. G., Benito, M. J., de Guía Córdoba, M., Alvarenga, N., \& de Herrera S. R. M. S. (2017). Yeast community in traditional Portuguese Serpa cheese by culturedependent and-independent DNA approaches. International journal of food microbiology, 262, 63-70 https://doi.org/10.1016/j.ijfoodmicro.2017.09.013

Edgar, R. C., Haas, B. J., Clemente, J. C., Quince, C., \& Knight, R. (2011). UCHIME improves sensitivity and speed of chimera detection. Bioinformatics, 27, 2194-2200. https://doi.org/10.1093/bioinformatics/btr381

Feutry, F., Oneca, M., Berthier, F, \& Torre, P. (2012). Biodiversity and growth dynamics of lactic acid bacteria in artisanal PDO Ossau-Iraty cheeses made from raw ewe's milk with different starters. Food Microbiology, 29, 33-42. https://doi.org/10.1016/j.fm.2011.08.011

Fratamico, P. M., Bagi, L. K., \& Pepe, T. (2000). A multiplex polymerase chain reaction assay for rapid detection and identification of Escherichia coli O157: H7 in foods and bovine feces. Journal of Food Protection, 174, 1032-1037. https://doi.org/10.4315/0362-028X-63.8.1032

Fuka, M. M., Wallisch, S., Engel, M., Welzl, G., Havranek, J., \& Schloter, M. (2013). Dynamics of bacterial communities during the ripening process of different Croatian cheese types derived from raw ewe's milk cheeses. PLoS One, 8, e80734. https://doi.org/10.1371/journal.pone.0080734

Galan, E., Cabezas, L., \& Fernández-Salguero, J. (2012). Proteolysis, microbiology and sensory properties of ewe's milk cheese produced with plant coagulant from cardoon $C y$ nara cardunculus, calf rennet or a mixture thereof. International Dairy Journal, 25, 92-96. https://doi.org/10.1016/j.idairyj.2012.02.001 
Giraffa, G. (2003). Functionality of enterococci in dairy products. International Journal of Food Microbiology, 88, 215-222. https://doi.org/10.1016/S0168-1605(03)00183-1

Guerreiro, O., Velez, Z., Alvarenga, N., Matos, C., \& Duarte, M. (2013). Molecular screening of ovine mastitis in different breeds. Journal of Dairy Science, 96, 752-760. https://doi.org/10.3168/jds.2012-5519

Guiné, R. P., Tenreiro, M. I., Correia, A. C., Correia, P. M., \& Barracosa, P. (2016). Analysis of factors influencing the physical, chemical and sensorial properties of Serra da Estrela cheeses. Journal of Food Measurement and Characterization, 10, 643-657. https://doi.org/10.1007/s11694-016-9348-6

Hemme, D., \& Foucaud-Scheunemann, C. (2004). Leuconostoc, characteristics, use in dairy technology and prospects in functional foods. International Dairy Journal, 14, 467-494 https://doi.org/10.1016/j.idairyj.2003.10.005

Herlemann, D. P. R., Labrenz, M., Jürgens, K., Bertilsson, S., Waniek, J. J., \& Andersson, A. F. (2011). Transition in bacterial communities along the $2000 \mathrm{~km}$ salinity gradient of the Baltic Sea. The ISME Journal, 5, 1571-1579. https://doi.org/10.1038/ismej.2011.41

Irlinger, F., Yung, S. A. Y. I., Sarthou, A. S., Delbès-Paus, C., Montel, M. C., Coton, E. . Helinck, S. (2012). Ecological and aromatic impact of two Gram-negative bacteria (Psychrobacter celer and Hafnia alvei) inoculated as part of the whole microbial community of an experimental smear soft cheese. International Journal of Food Microbiology, 153, 332-338. https://doi.org/10.1016/j.ijfoodmicro.2011.11.022

ISO 5534:2004 (en). Cheese and processed cheese - Determination of the total solids content (Reference method). Geneva, Switzerland: International Organization for Standardization,

ISO 11290-2:1998/A1:2004. (1998). Microbiology offood and animal feeding stuffs—horizontal method for the detection and enumeration of Listeria monocytogenes, Part 1: Detection method. Geneva, Switzerland: International Organization for Standardization,

ISO 6785:2001 (IDF 93:2001). (2001). Milk and milk products-detection of Salmonella spp. Geneva, Switzerland: International Organization for Standardization

Klindworth, A., Pruesse, E., Schweer, T., Peplies, J., Quast, C., Horn, M., \& Glöckner F. O. (2013). Evaluation of general 16S ribosomal RNA gene PCR primers for classical and next-generation sequencing-based diversity studies. Nucleic Acids Research, 28, 1-11. https://doi.org/10.1093/nar/gks808

Kornaki, L. J., \& Johnson, J. L. (2001). Enterobacteriaceae, coliforms and Escherichia coli as quality and safety indicators. In F. P. Downes, \& K. Ito (Eds.), Compendium of Methods for the microbiological examination of foods (4th ed., pp. 69-82). Washington DC: American Public Health Association,

Le Loir, Y., Baron, F., \& Gautier, M. (2003). Staphylococcus aureus and food poisoning. Genetics and Molecular Research, 2, 63-76.

Little, C. L., Rhoades, J. R., Sagoo, S. K., Harris, J., Greenwood, M., Mithani, V., . . McLauchlin, J. (2008). Microbiological quality of retail cheeses made from raw, thermized or pasteurized milk in the UK. Food Microbiologr, 25, 304-312. https://doi.org/10.1016/j.fm.2007.10.007

McSweeney, P. L. H., \& Sousa, M. J. (2000). Biochemical pathways for the production of flavour compounds in cheeses during ripening. A review. Lait, 80, 293-324 https://doi.org/10.1051/lait:2000127

Menéndez, S., Centeno, J. A., Godínez, R., \& Rodríguezâ€“Otero, J. L. (2000). Effects of various Lactobacillus strains on the ripening and organoleptic characteristics of Arzúa-Ulloa cheese. International Journal of Food Microbiology, 59, 37-46. https://doi.org/ 10.1016/S0168-1605(00)00286-5

Montet, M. P., Jamet, E., Ganet, S., Dizin, M., Miszczycha, S., Duniere, L., ... VernozyRozand, C. (2009). Growth and survival of acid-resistant and non-acid-resistant Shiga-toxinproducing Escherichia coli strains during the manufacture and ripening of Camembert cheese. International Journal of Microbiology, 1-10. https://doi.org/10.1155/2009/653481

Moreno, M. F., Sarantinopoulos, P., Tsakalidou, E., \& De Vuyst, L. (2006). The role and application of enterococci in food and health. . International Journal of Food Microbiology, 106, 1-24. https://doi.org/10.1016/j.ijfoodmicro.2005.06.026

Nieto-Arribas, P., Seseña, S., Poveda, J. M., Palop, L., \& Cabezas, L. (2010). Genotypic and technological characterization of Leuconostoc isolates to be used as adjunct starters in Manchego cheese manufacture. Food Microbiology, 27, 85-93. https://doi.org/10.1016/j.fm.2009.08.006
Ordiales, E., Benito, M. J., Martín, A., Casquete, R., Serradilla, M. J., \& Córdoba, M. G. (2013a). Bacterial communities of the traditional raw ewe's milk cheese "Torta del Casar, " made without the addition of a starter. Food Control, 33, 448-454. https://doi.org/10.1016/j.foodcont.2013.03.027

Ordiales, E., Martín, A., Benito, M. J., Hernández, A., Ruiz-Moyano, S., \& Córdoba, M. G. (2013b). Role of the microbial population on the flavor of the soft-bodied cheese Torta del Casar. Journal of Dairy Science, 96, 5477-5486. https://doi.org/10.3168/jds.2013-6587

Ortigosa, M., Irigoyen, A., Urdin, M., García, S., Ibanez, F. C., \& Torre, P. (2008). Sources of enterococci in Idiazábal-type cheese. International Journal of Food Microbiology, 125, 146-152. https://doi.org/10.1016/j.ijfoodmicro.2008.03.035

Öztürk, M., \& Meterelliyöz, M. (2015). Practical identification of human originated Lactobacillu. species by amplified ribosomal DNA restriction analysis (ARDRA) for probiotic use. Molecular Biology Reports, 42, 1323-1332. https://doi.org/10.1007/s11033-015-3877-7

Pereira, C. I., Graça, J. A., Ogando, N. S., Gomes, A. M. P., \& Malcata, F. X. (2010a). Influence of bacterial dynamics upon the final characteristics of model Portuguese traditional cheeses. Food Microbiology, 27, 339-346. https://doi.org/10.1016/j.fm.2009.10.012

Pereira, C. I., Neto, D. M., Capucho, J. C., Gião, M. S., Gomes, A. M. P., \& Malcata, F. X. (2010b). How three adventitious lactic acid bacteria affect proteolysis and organic acid production in model Portuguese cheeses manufactured from several milk sources and two alternative coagulants. Journal of Dairy Science, 93, 1335-1344. https://doi.org/10.3168/jds.2009-2294

Picon, A., Garde, S., Ávila, M., \& Nuñez, M. (2016). Microbiota dynamics and lactic acid bacteria biodiversity in raw goat milk cheeses. International Dairy Journal, 58, 14-22. https://doi.org/10.3168/jds.2009-2294

Quigley, L., O'Sullivan, O., Beresford, T. P., Ross, R. P., \& Fitzgerald, G. F. (2011). Molecular approaches to analyzing the microbial composition of raw milk and raw milk cheese. Internationa Journal of Food Microbiology, 150, 81-94. https://doi.org/10.1016/j.ijfoodmicro.2011.08.001

Rola, J. G., Czubkowska, A., Korpysa-Dzirba, W., \& Osek, J. (2016). Occurrence of Staphylococcus aureus on farms with small scale production of raw milk cheeses in Poland. Toxins, 8, 62. https://doi.org/10.3390/toxins 8030062

Roseiro, L. B., Wilbey, R. A., \& Barbosa, M. (2003). Serpa cheese: Technological, biochemical and microbiological characterisation of a PDO ewe's milk cheese coagulated with Cynara cardunculus L. Lait, 83, 469-481. https://doi.org/10.1051/lait:2003026

Ruggirello, M., Cocolin, L., \& Dolci, P. (2016). Fate of Lactococcus lactis starter culture during late ripening in cheese models. Food Microbiology, 59, 112-118. https://doi.org/ 10.1016/j.fm.2016.05.001

Ruggirello, M., Dolci, P., \& Cocolin, L. (2014). Detection and viability of Lactococcus lactis throughout cheese ripening. PLoS One, 9, e114280. https://doi.org/10.1371/ journal.pone. 0114280

Schmieder, R., \& Edwards, R. (2011). Quality control and preprocessing of metagenomic datasets. Bioinformatics, 27, 863-864 https://doi.org/10.1093/bioinformatics/btr026

Schubert, M., Lindgreen, S., \& Orlando, L. (2016). AdapterRemoval v2: Rapid adapte trimming, identification, and read merging. BMC Research Notes, 9, 88. https://doi.org/ 10.1186/s13104-016-1900-2

Stewart, C. M., Cole, M. B., Legan, J. D., Slade, L., Vandeven, M. H., \& Schaffner, D. (2002). Staphylococcus aureus growth boundaries: Moving towards mechanistic predictive models based on solute-specific effects. Applied and Environmental Microbiology, 68, 1864-1871. https://doi.org/10.1128/AEM.68.4.1864-1871.2002

Tabla, R., Gómez, A., Simancas, A., Rebollo, J. E., Molina, F., \& Roa, I. (2016). Enterobacteriaceae species during manufacturing and ripening of semi-hard and soft raw ewe's milk cheese: Gas production capacity. Small Ruminant Research, 145, 123-129. https://doi.org/10.1016/j.smallrumres.2016.11.008

Tavaria, F. K., \& Malcata, F. X. (1998). Microbiological characterization of Serra da Estrela cheese throughout its Appellation d'Origine Protegee region. Journal of Food Protection, 61, 601-607. https://doi.org/10.4315/0362-028X-61.5.601 